УДК 82I.ІІІ

ББК 83.3(4Вел)5
ДВА ЖЕНИХА И ДВА СОНЕТА:

О ПОЭТИЧЕСКИХ ФОРМАХ

В «РОМЕО И ДЖУЛЬЕТТЕ»

DOI: I0.22455/2500-4247-20I7-2-3-94-II7

Аннотация: Статья посвящена вопросам семиотики сонетной формы, использованной в шекспировской трагедии «Ромео и Джульетта». Особое внимание уделено сонетам двух женихов Джульетты, в которых отразились разные типы любовных ухаживаний. Шекспироведы многократно обсуждали в научной печати поэтическое «подношение» от Ромео Джульетте, сонетный диалог во время бала (Act I, Sc. 5, ls. 92-Іо9). Другой сонет-ухаживание - от лица Париса, произнесенный матушкой Капулетти (Act I, Sc. 3, ls. 8o-95), - читатели и исследователи обычно обходят молчанием. В этой статье сопоставлены сонеты Ромео и Париса, построенные на основе развернутых метафор (кончетто). Сонет Ромео обладает большим запасом драматической энергии, которая реализуется в непринужденном споре и сплочении заглавных героев. Семантическая заряженность этого сонетного диалога подсказывает сценический рисунок ролей, предопределяет общий ход событий. В противовес этой поэтической вставке, сонет Париса статичен, сообразен мертвой букве книжного наставления, не предполагает диалога между влюбленными и не волнует Джульетту. В статье также уделено внимание перекличке сонетов Ромео и Париса с сонетами І28 и І26 шекспировского цикла, опубликованного в I6о9 г.

Ключевые слова: вставные сонеты, сонет-диалог, усеченный сонет, сонет из двустиший, эксперименты Шекспира с формой сонета.

Информация об авторе: Елена Владимировна Халтрин-Халтурина - доктор филологических наук (РФ), PhD in English (USA), ведущий научный сотрудник, Институт мировой литературы им. А.М. Горького Российской академии наук, ул. Поварская, д. 25 а, І2І069 Москва, Россия.

E-mail: elenahaltrin@yandex.ru, el.haltrin@imli.ru 


\section{TWO WOOERS AND THEIR SONNETS: ON POETIC FORMS IN ROMEO AND JULIET}

This is an open access article

distributed under the Creative

Commons Attribution 4.0

International (CC BY 4.0)
(C) 20I7. E.V. Haltrin-Khalturina,

A.M. Gorky Institute of World Literature

of the Russian Academy of Sciences, Moscow, Russia

Received: February 28, 2017

Date of publication: September 25, 2017

Abstract: The article looks at the semiotics of the sonnet form used by Shakespeare in his tragedy Romeo and Juliet. Particular attention is paid to two sonnets, of Paris and of Romeo, in which different manners of courting are played out. The poetic "gift" from Romeo to Juliet, their shared sonnets, one complete and one interrupted (Act I, Sc. 5, ls. 92-Io9), is a notorious and much discussed piece of Shakespeare's dramatic poetry. However, the other wooing sonnet representing desires of Paris and mouthed by Lady Capulet (Act I, Sc. 3, 1s. 80-95), seems to lack that kind of attention. Our essay juxtaposes the two sonnets in question, which are built around extended metaphors (conceits). Romeo's sonneteering is endowed with dramatic power that quickens the debate and inspires accord between the title's heroes. The semantic charge of this shared sonnet resonates in the heroes' scenic gestures, prompting the play's outcome. By contrast, the rather inert sonnet of Paris is like a dead letter of bookish instruction, which neither inspires amorous response, nor moves Juliet. The article also places Romeo's and Paris's pieces against Shakespeare's sonnets I 28 and 126 of the I6o9 edition.

Keywords: inset sonnets, shared sonnet, truncated sonnet, sonnet written in couplets, Shakespeare's experiments with the sonnet form.

Information about the author: Elena V. Haltrin-Khalturina, DSc in Philology, PhD in English (USA), Leading Research Fellow, A.M. Gorky Institute of World Literature of the Russian Academy of Sciences, Povarskaya 25 a, Moscow I21069, Russia.

E-mail: elenahaltrin@yandex.ru, el.haltrin@imli.ru 
На титульном листе первого печатного издания «Ромео и Джульетты» (QI,

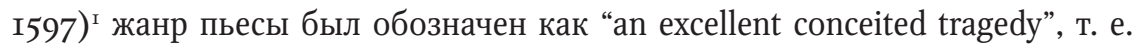
«превосходнейшая трагедия, исполненная кончетто», - указание, снятое со всех последующих, непиратских изданий. О приемах использования кончетто в шекспировской комедии и о значении высказывания "conceited comedy” нам уже приходилось говорить [7, с. 73I-733]: остроумные развернутые метафоры (кончетто) нередко вызывают улыбку. Однако что касается подзаголовка откровенно печальной истории, то сочетание "conceited tragedy” воспринимается здесь как неуместный оксюморон, который заслоняет собой и сводит на «нет» глубину горестных переживаний. Не случайно этот подзаголовок был снят с «законных» изданий пьесы. Ведь в трагедии красота речи и юмор должны не нивелировать печальную составляющую, а оттенять и высвечивать ее.

Сочетание острой грусти и красивого слова, россыпь дивных поэтических форм - вот чем богата трагедия «Ромео и Джульетта». Обращал внимание на поэтичность языка этой пьесы и А.С. Пушкин, сказавший, что в шекспировской пьесе «Ромео и Джульетта» «отразилась Италия, совре-

I Напомним: по сведениям текстологов, пьеса была написана около I595 г. В 1597 г. вышло ее первое печатное издание, которое сегодня называют «плохим» или «пиратским» кварто. Предположительно текст для этого кварто воспроизводили актеры, помнившие свои реплики лучше, чем остальные части трагедии. B I599 г. по черновику Шекспира было напечатано новое - «исправленное» - издание «Ромео и Джульетты». Это второе кварто «Превосходнейшая и наиплачевная трагедия о Ромео и Джульетте» (“The Most Excellent and Lamentable Tragedy of Romeo and Juliet”) - и является основой для современных републикаций и переводов пьесы. Мы цитируем пьесу по: [15]. 
менная поэту, с ее <...> сонетами, с ее роскошным языком, исполненным блеска и concetti» [6]. Современные комментаторы трагедии тоже обязательно упоминают присутствие в ней развернутых метафор и оригинальных сонетов [I7, loc. 437].

Разумеется, сонетный дух воцарился в «Ромео и Джульетте» не случайно: к г590-м гг. в Великобритании, благодаря творчеству Сидни, Спенсера и Дэниела, сонет зарекомендовал себя как поэтическая форма, идеальная для воплощения любовных переживаний. Примечательно, однако, что изощренность этой твердой формы, которая, казалось бы, не отвечает запросам живых диалогов (сонеты в Англии того времени широко циркулировали в списках и являлись частью рукописной и книжной культуры), не помешала Шекспиру применять сонет для самых разнообразных драматических нужд.

Трагедию «Ромео и Джульетта» Шекспир структурировал особым образом. Пьесу отличает необыкновенная стремительность развития действия. Здесь почти что можно говорить о предвосхищении Шекспиром классицистического правила единства времени. Все события трагедии «Ромео и Джульетта» укладываются в одну неполную неделю июля. Небывалая любовь героев очень быстротечна: они знакомятся в воскресный вечер, венчаются в понедельник, расстаются на заре во вторник и погибают в ночь со среды на четверг (о таком раскладе событий по дням и часам см.: [I7, loc. 842]).

Еще одна особенность пьесы - ее насыщенность всяческими разножанровыми и разностилевыми вставками. Здесь и музыкально-танцевальные номера (танцы на балу, шествие с факелами, элементы маски, элементы пантомимы, выступление приглашенных музыкантов $)^{2}$. Здесь и декламации, которые нельзя не упомянуть: панегирик

2 Обыкновение елизаветинцев сочетать танцевальные жесты с сопроводительными речами отмечает на примере английской маски шекспировского времени балерина и искусствовед В.M. Красовская: «Как театральный жанр маска утвердилась к концу XVI в. при дворе Елизаветы, пройдя примерно тот же путь, что и танцевальные интермедии в Италии и Франции. Свободную импровизацию здесь также сменила упорядоченная планировка танца костюмированных персонажей, а поэты в стихах объясняли действие. <..> [В то же время] принцип свободного варьирования не столько темы, сколько на тему, принцип окружения центрального замысла венком разнообразных эпизодов свойствен и маске» [2, с. 78]. Интересно замечание исследователя о том, что скорее поэтическое слово структурировало танец, нежели наоборот: «Вместе с музыкой на регламентацию танца 
в адрес царицы Мэб (повитухи фей), произнесенный Меркуцио в начале пьесы; словесное сражение между Меркуцио и Тибальтом, разыгранное одновременно с их сражением на шпагах; эпиталама (свадебная песнь), вложенная в уста Джульетты (начало 2-й сцены 3-го акта); альба (утреннее прощание Ромео и Джульетты и их спор о соловье и жаворонке, акт 3 , сц. 5); элегия, произнесенная Парисом в память «почившей» Джульетты. В пьесе имеется несколько клятв, а также речей на смертном одре. К другим, если можно так сказать, «церемониальным речам», относятся: приговор герцога об изгнании нарушителя порядка, предсмертная речь Меркуцио со своеобразным рефреном «Чума на оба Ваших дома», который в силу многократного повторения приобретает весомость проклятия. Слуги обоих домов - Капулетти и Монтекки - в перепалках часто прибегают к грубой брани. Монах Лоренс тяготеет к кратким изречениям нравоучительного характера (типа сентенций) и к стилю проповеди. Временами с его уст срывается нечто напоминающее проповедь-пророчество, хотя пророчествует он не об истине Божией, а о судьбе героев, чья жизнь проходит перед нами: «Тем, кто спешит, грозит паденье» предупреждает Лоренс нетерпеливого Ромео.

Насыщая пьесу регламентированными элементами, Шекспир обнаруживает виртуозное владение драматической «техникой» и включает в пьесу элементы вольной поэтической игры, импровизации. Как именно это выглядит, мы рассмотрим на примере двух инкорпорированных в трагедию сонетов, в которых воплотились сердечные чаяния двух разных претендентов на руку Джульетты: Ромео и Париса.

Эти два любовных сонета - далеко не самые приметные в тексте трагедии. Мимо них легко «проскочить», обратив внимание совсем на другие поэтические вставки: сонеты-прологи перед первым и вторым актом. В прологах Хор сообщает, что за трагедия разыгрывается на сцене. Приведем их в переводе Т.Л. Щепкиной-Куперник:

влияла английская поэзия. Известна поэма ученого юриста Джона Девиса “Оркестра, или Поэма о танце” (1596). Сюжет там таков: красавец Антиной, чтобы завоевать сердце Пенелопы, жены Улисса, рассказывает ей, как Любовь дала миру Танец, создав таким образом порядок в природе и у людей. Танцевальные размеры Девис объяснял терминами поэзии» [2, c. 79]. 
В двух семьях, равных знатностью и славой,

В Вероне пышной разгорелся вновь

Вражды минувших дней раздор кровавый,

Заставил литься мирных граждан кровь.

Из чресл враждебных, под звездой злосчастной,

Любовников чета произошла.

По совершенье их судьбы ужасной

Вражда отцов с их смертью умерла.

Весь ход любви их, смерти обреченной,

И ярый гнев их близких, что угас

Лишь после гибели четы влюбленной, -

Часа на два займут, быть может, вас.

Коль подарите нас своим вниманьем,

Изъяны все загладим мы стараньем.

Первый пролог излагает суть трагедии, а также призывает зрителей к тишине и вниманию. Следующий пролог, размещенный перед вторым актом, кажется вовсе излишним: он едва ли откроет зрителю что-то неожиданное.

Былая страсть поглощена могилой -

Страсть новая ее наследства ждет,

И та померкла пред Джульеттой милой,

Кто ранее была венцом красот.

Ромео любит и любим прекрасной.

В обоих красота рождает страсть.

Врага он молит; с удочки опасной

Она должна любви приманку красть.

Как враг семьи заклятый, он не смеет

Ей нежных слов и клятв любви шепнуть. 
Настолько же надежды не имеет

Она его увидеть где-нибудь.

Но страсть даст силы, время даст свиданье

И сладостью смягчит все их страданья.

(Пер. Т.Л. Щепкиной-Куперник)

Тем не менее и этот сонет-пролог сценически необходим. Требуется выиграть время, чтобы Ромео, ушедший со сцены после диалога с Джульеттой и кормилицей (акт I, сц. 5), успел сцену обогнуть и выйти на нее с другой стороны (начало акта 2, сц. I), дабы «подслушать» шутки в свой адрес, которые отпускают Меркуцио и Бенволио [г, p. XV].

Главная художественная роль этих прологов обнаруживается не сразу. «Сухие» сонеты Хора, взятые вместе, образуют контрастное обрамление для третьего сонета - I4-стишия совершенно иного рода, размещенного в пространстве между ними: в пятой сцене первого акта (act I, sc. 5, 1s. 92-Іо5; 1s. I06-I09). Имеется в виду диалог Ромео и Джульетты на балу, о котором много говорилось в литературоведении [5; 7; II; І2; І13]. Насколько сонеты-прологи публичны, формальны и бесстрастны, настолько сонет-диалог интимен и полон чувства. Рассмотрим его.

\section{Сонет Ромео}

Любовное подношение Джульетте от Ромео - это отнюдь не сонет-монолог влюбленного, обращенный к бессловесной даме. Скорее это сонетный «диспут» (в смысле “debate”, напоминающий диалогические эклоги), свершающийся на глазах зрителя. В устах заглавных героев совершенный английский сонет легко, без натуги, рождается как бы сам по себе - прямо в живом диалоге. С обеих сторон - с мужской и женской мысль, развиваемая в сонете, получает подпитку, а взаимно нарастающее чувство - поддержку. В сложении катренов и куплета, октета и сестета Ромео и Джульетта проявляют равные усилия. Они равноправные творцы совершенного - поистине обоюдного - сонета. 
Romeo: If I profane with my unworthiest hand

This holy shrine, the gentle sin is this:

My lips, two blushing pilgrims, ready stand

To smooth that rough touch with a tender kiss.

Juliet: Good pilgrim, you do wrong your hand too much,

Which mannerly devotion shows in this;

For saints have hands that pilgrims' hands do touch,

And palm to palm is holy palmers' kiss.

Romeo: Have not saints lips, and holy palmers too?

Juliet: $\quad$ Ay, pilgrim, lips that they must use in prayer.

Romeo: $\quad$ O then, dear saint, let lips do what hands do!

They pray: grant thou, lest faith turn to despair.

Juliet: $\quad$ Saints do not move, though grant for prayers' sake.

Romeo: $\quad$ Then move not, while my prayers' effect I take.

(He kisses her)

Ромео: Коль обижает грешная Рука

Святыню эту смелым прикасаньем,

Как два Паломника мои Уста

Загладят грех смиренным целованьем.

Джульетта: Паломник милый! Вы к Руке строги,

Она не заслужила порицанья:

Касаются с почтеньем и святых.

Ладонь к ладони - чем не целованье?

Ромео: $\quad$ Но есть ведь у паломников уста?

Джульетта: Уста творят молитву, милый друг!

Ромео: $\quad$ Молитву, Лик небесный?! Вот она:

Пусть следуют Уста примеру Рук! 
Джульетта: Тих лик небес - но слышат там мольбу.

Ромео: $\quad$ Что ж, будь тиха - я плод молитв приму.

(целует ее)

(Пер. Е. Халтрин-Халтуриной)

Образной основой для диспута служит развернутая метафора, изображающая паломников и объекты их чинных поклонений. Ромео и Джульетта дискутируют о том, прилично ли пилигримам прикладываться к святыне устами. Пилигрим, которого изображает Ромео, получает свыше (от «святыни» - Джульетты) негласное одобрение: она не противится проявлению благих чувств и поддерживает паломника в его искренних порывах. Прикосновение становится взаимным. А целованье, упомянутое в стихах, материализуется на сцене: превращается в настоящий, живой поцелуй. Так религиозной символикой освящается в этом диспуте любовь юноши и девушки. От этого шекспировского кончетто рукой подать до дерзких метафизических метафор Джона Донна («Канонизация», «Блоха», «К восходящему солнцу» и др.).

Интересна звуковая и стилистическая сторона сонета-диспута. Мужской и женский голос здесь ритмично чередуются, перекликаются эхом, сливаются в одну мелодию. В диалоге много слогов и слов, которые молодые люди повторяют друг за другом голосом и губами. Реплики Ромео и Джульетты переплетаются, образуют различные фигуры речи. Быстрая смена реплик героев (стихомифия) - вплоть до членения диалога на полустишия (hemistichomythia; см. продолжение диалога после поцелуя) - обнаруживает пылкость чувств и зажигательный темперамент говорящих. В сонете используется прием амплификации (повторение отдельных слов и речевых конструкций, накопление синонимов), результатом которого становится изменение значения и значимости слова «целованье» (kiss). Само это слово выделено рифмой и эпифорой (одинаковые окончания строф). Диалог достигает своей кульминации, когда эпифора «поцелуй» актуализируется в действиях Ромео и Джульетты: слово воплощается в дело.

Схожий прием превращения слова «поцелуй» (kiss) в живой жест после переосмысления разного вида касаний пальцев, рук и губ, использован Шекспиром и в сонетах цикла І6о9 г. Я имею в виду І28 сонет, в кото- 
ром тоже заложен большой перформативный потенциал: сонет этот вполне можно инсценировать:

How oft when thou, my music, music play'st, Upon that blessed wood whose motion sounds With thy sweet fingers when thou gently sway'st The wiry concord that mine ear confounds,

Когда на свет, о музыка моя, Из дерева ты музыку зовешь, То в пальцах столько дивного чутья, Что мой восторг меня приводит в дрожь.

Do I envy those jacks that nimble leap, Я клавишам завидую тогда. To kiss the tender inward of thy hand, Они с тобою нежно говорят, Whilst my poor lips which should that harvest reap, Покуда губы, не сорвав плода, At the wood's boldness by thee blushing stand! Поодаль от смущения горят.

To be so tickled, they would change their state And situation with those dancing chips,

O'er whom thy fingers walk with gentle gait, Making dead wood more bless'd than living lips.

Since saucy jacks so happy are in this, Give them thy fingers, me thy lips to kiss.
Я этим звонким щепкам все отдам За нежное касанье рук твоих. Ты пальцы рассылаешь по ладам, И дерево счастливей губ живых.

Как примирить нас, долго не гадай:

Ты пальцы им, а губы мне отдай. (Пер. Игн. Ивановского)

О том, какое звучание получал сонет Ромео и Джульетты на сцене, какими жестами следует сопровождать его чтение, имеются разные мнения. Поскольку знакомство героев состоялось во время бала, не исключено, что Ромео и Джульетта исполняют диалог-сонет во время танца. Вероятно, Ромео подает девушке руку. Жестом же он может дать понять, что к ней относится и слово «святыня». Джульетта в свою очередь совмещает свои ответы с красноречивыми сложениями рук. Многие постановщики пьесы синхронизируют диалог-сонет и пластический рисунок танца. Например, в знаменитой экранизации I936 г. актеры произносят это г4-стишие, исполняя павануз.

3 «Подробное описание простой паваны, представляющей собой танец, в ходе которого пары двигались вперед, поочередно исполняя простые и двойные шаги, дано в “Орхезо- 


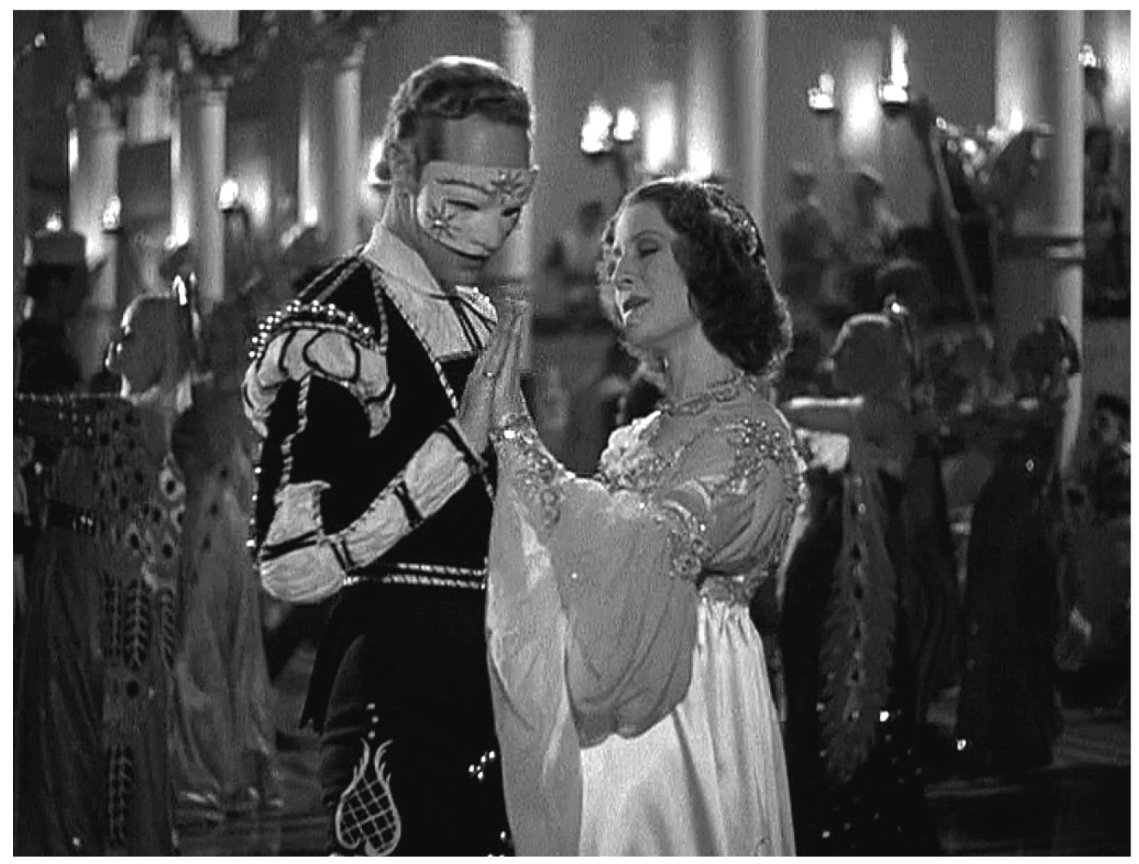

Сонетный диалог Ромео и Джульетты во время танца. Экранизация I936 г., голливудская студия MGM.

(В роли Ромео - Лесли Ховард, Джульетты - Норма Ширер; режиссер Джордж Кьюкор)

Romeo and Juliet share their sonnet while dancing. The I936 film adaptation, MetroGoldwyn-Mayer. (Leslie Howard as Romeo, Norma Shearer as Juliet; directed by George Cukor)

Конечно, павана - это «торжественный процессиальный танец» [4, с. Іо6], исполнители которого находятся у всех на виду. Личного пространства у танцоров не так много, и обмен замедленным трепетным поцелуем в этот танец вписать непросто (как, впрочем, и в исполнение алеманды, куранты и даже гальярды). Вот почему хотя бы часть сонета читается Ромео и Джульеттой в стороне от танцующей толпы.

графии” Арбо. Продолжительность танца была произвольной и зависела от музыкального сопровождения. Из описания паваны у Арбо не следует, исполнялась ли она одной или несколькими парами в колонну, но, судя по иконографии и традиции исполнения бассдансов того же периода, исполнение танца всеми парами в колонну вполне вероятно» [4, с. Iо7]. Музыка, под которую двигаются актеры в фильме 1936 г., - это павана из Арбо в современной обработке. В титрах указания на павану нет. 
Некоторые исследователи склонны вовсе выносить сонет за пределы общего танцевального шествия. Так, Алан Бриссенден, знаток литературы и балов эпохи Тюдоров, посвятивший танцам шекспировских пьес специальную монографию [9], полагает, что на сцене Ромео и Джульетта, произносящие сонет, не танцуют. Бал и музыка служат для их диалога лишь фоном [9, с. 63-65]. Пластика движений героев в этом контексте ближе к пантомиме, чем к танцу. Не случайно после бала Джульетта, говоря о юном Ромео своей старой кормилице, описывает его как «не любителя танцевать» (“hе $<\ldots>$ that would not dance", act I, sc. 5, ln. I30).

По мнению Бриссендена, нежелание Ромео участвовать в общей кутерьме, будь то танцевальное шествие или уличные бои, выделяет героя из группы других персонажей пьесы и придает ему особый “лирический” статус. И в танцах, и в драке Ромео - скорее зритель, нежели участник. Когда он подходит к Джульетте и протягивает к ней руку, словно приглашает на танец, он действует не по привычке и не по указке танцмейстера, а по зову души. Когда он вынужден схватиться за оружие и отплатить Тибальту за смерть Меркуццио - это тоже исключительный случай. Ромео дерется не потому, что он обязательный участник уличных боев. Совсем наоборот: затевать ссору не в его характере. Тем горше ирония финала дуэли. Ромео наказан и изгнан за смертоубийство, которое он пытался предотвратить.

Но вернемся к сонету-диалогу. На поцелуе сонетные речи Ромео и Джульетты не обрываются. Разомкнув губы, юные герои сразу начинают создавать следующий сонет, который прервется из-за вторжения кормилицы, явившейся звать Джульетту к матушке (в шекспироведческой литературе традиционно считается, что за сонетом-диалогом Ромео и Джульетты следует катрен оборванного сонета. См., например: [I7, loc. 705; I4, с. 64-68]).

В переводе Т.Л. Щепкиной-Куперник это выглядит следующим образом:

Ромео. К Когда рукою недостойной грубо Я осквернил святой алтарь - прости. Как два смиренных пилигрима, губы Лобзаньем смогут след греха смести. 
Джульетта. Любезный пилигрим, ты строг чрезмерно

К своей руке: лишь благочестье в ней.

Есть руки у святых: их может, верно,

Коснуться пилигрим рукой своей.

Ромео. Даны ль уста святым и пилигримам?

Джульетта. Да, - для молитвы, добрый пилигрим.

Ромео. Святая! Так позволь устам моим

Прильнуть к твоим - не будь неумолима.

Джульетта. Не двигаясь, святые внемлют нам.

Ромео. Недвижно дай ответ моим мольбам.

(Целует её.)

Твои уста с моих весь грех снимают.

Джульетта. Так приняли твой грех мои уста?

Ромео. Мой грех... О, твой упрек меня смущает!

Верни ж мой грех.

Джульетта.

Вина с тебя снята.

Кормилица. Синьора, ваша матушка вас просит.

Прозаическая реплика кормилицы, которая не пожелала заметить, какое таинство свершалось на ее глазах, вносит диссонанс в дуэт двух влюбленных. Поэтическая гармония оказывается нарушена, I4-стишие оборвано. Неожиданно прерванный сонетный диалог Ромео и Джульетты обретает весомость зловещего предсказания - становится символом оборвавшейся жизни заглавных героев.

Далее (после начала акта 2) сонеты в пьесе не встречаются. Имеется лишь одно шестистишие, которое можно присоединить к сонету, прерванному кормилицей, как некое подобие концовки. Я говорю о самых последних, заключительных строках пьесы, произнесенных герцогом Веронским. Если дополнить упомянутым сестетом оборвавшуюся беседу Ромео и Джульетты, то получим следующий составной сонет: 
Ромео. $\quad$ Твои уста с моих весь грех снимают.

Джульетта. Так приняли твой грех мои уста?

Ромео. Мой грех... О, твой упрек меня смущает!

Верни ж мой грех.

Джульетта.

Вина с тебя снята.

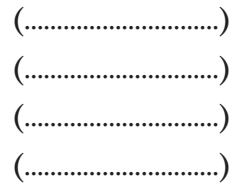

Герцог. Лик прячет с горя в облаках густых.

Идём, рассудим обо всём, что было.

Одних - прощенье, кара ждет других.

Но нет печальней повести на свете, Чем повесть о Ромео и Джульетте.

В начале этого составного сонета - мотив «снятия греха» чистым поцелуем любви; в конце - переживание катарсиса. На одном краю - дуэт Ромео и Джульетты; на другом - голос правителя их родного города, вещающий о печали и искуплении. Между этими полюсами - зияние пропущенного катрена, немое неприятие «совершенья их судьбы ужасной».

Пропущенный, немой катрен вмещает многое. Это гиблая «зона», где всё «пошло наперекос» и к чистому поцелую любви была подмешана отрава. Ее источники - давняя вражда кланов Монтекки и Капулетти, а также разлаженность действий Ромео и его наставника Лоренцо.

Предсмертная реплика Ромео, вспоминающего поцелуй Джульетты и склоняющегося над ее спящим телом, "Here’s to my love! O true apothecary, / Thy drugs are quick. Thus with a kiss I die.” (act V, sc. 3, ls. II9-I20), звучит как эхо их первого сонета-диалога. Подхватывает это эхо и пробудившаяся Джульетта: 
Что вижу я! В руке Ромео склянка!

Так яд принес безвременную смерть.

О жадный! Выпил все и не оставил

Ни капли милосердной мне на помощь!

Тебя я прямо в губы поцелую.

Быть может, яд на них еще остался, -

Он мне поможет умереть блаженно.

(Целует Ромео.)

Уста твои теплы.

(Пер. Т.Л. Щепкиной-Куперник)

Этот поцелуй, как и в первом диалоге влюбленных, оказывается прерван чужим вторжением. Услышав чьи-то приближающиеся шаги, Джульетта находит на теле Ромео кинжал и вонзает его в себя, утверждая, что для его клинка нет лучших ножен (еще одно актуализированное кончетто).

Сегодня тайна диалога Ромео и Джульетты - диалога, воплощенного в «целовальном» І4-стишии (эхо которого звучит и в конце пьесы), известна каждому шекспироведу. Однако в «Ромео и Джульетте» имеется еще один сонет-ухаживание, на который читатели и исследователи практически никогда не обращают внимание. Назовем его «сонетом Париса», ибо он является частью сватовского обряда первого жениха Джульетты. Влюбленный Парис просит руки девушки у ее родителей, а затем его голос опосредованно звучит в речи матушки Джульетты: леди Капулетти говорит дочери о брачном сговоре, нахваливая будущего зятя.

\section{Сонет Париса}

Итак, создал ли Парис какое-нибудь «сонетное подношение» Джульетте? Коль скоро Джульетта не отвечала ему взаимностью, то, разумеется, ни о каком подобии сонета-диалога здесь речи идти не может. Парис и не пытался лично объясняться с Джульеттой языком пылкой поэзии: как и подобало благовоспитанному юноше знатного рода, он честно-благородно соблюдал все приличествующие случаю условности. Поэтическим голосом Париса становится будущая теща - мать Джульетты. В объеме трех сонетных катренов леди Капулетти старается нарисо- 

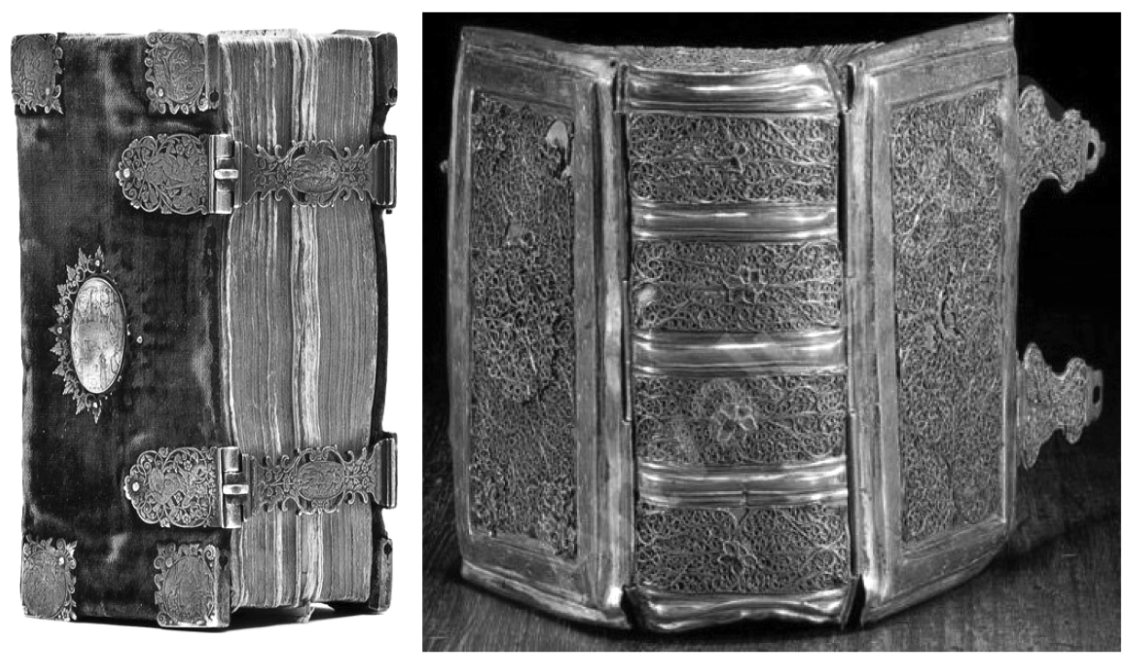

Старинные книги с «застежками» Antique books with clasps

вать для своей дочери лестный портрет посватавшегося Париса - «Читай, как книгу, юный лик Париса...». Приведем эту речь в образном и хорошо запоминающемся переводе Т.Л. Щепкиной-Куперник (перевод не эквилинеарен оригиналу), а затем только поговорим об использованной Шекспиром форме.

Читай, как книгу, юный лик Париса,

В нем красотой начертанную прелесть.

Вглядись в черты, которых сочетанье

Особое таит очарованье;

И все, что скрыто в чудной книге той,

Ты в выраженье глаз его открой.

Как книга без обложки, он лишь ждет,

Какой его украсит переплет.

Но не поймал никто еще той рыбы,

Чью кожу взять на переплет могли бы.

Да, смело может красота гордиться,

Коль эти заключит в себе страницы. 
Когда рассказ прекрасный в книге скрыт,

То ею всякий больше дорожит.

Ценней ее застежка золотая,

Смысл золотой собою охраняя.

Так раздели, что есть в его судьбе;

Не станешь меньше, взяв его себе.

Очевидно, что в центре монолога леди Капулетти - эротическая развернутая метафора. Парис нарисован как книга с ценным содержанием, а Джульетта - как драгоценная обложка («чехол» с застежками, «футляр») вместилище, предназначенное для этой книги. (Ср. предсмертное кончетто Джульетты, которая предпочла сделаться иным вместилищем - ножнами для клинка Ромео).

Теперь приведем речь леди Капулетти в оригинале и в переводе Б.Л. Пастернака:

What say you? can you love the gentleman? This night you shall behold him at our feast;

Read o'er the volume of young Paris' face, And find delight writ there with beauty's pen;

Examine every married lineament,

And see how one another lends content

And what obscured in this fair volume lies

Find written in the margent of his eyes.

This precious book of love, this unbound lover,

To beautify him, only lacks a cover:

The fish lives in the sea, and 'tis much pride

For fair without the fair within to hide:

That book in many's eyes doth share the glory, Картина требует красивой рамы,

That in gold clasps locks in the golden story;

So shall you share all that he doth possess, By having him, making yourself no less. (R\&J, act I, sc. 3, ls. 8I-94)
Что скажешь? По сердцу ли он тебе? Сегодня на балу его изучишь.

Прочти, как в книге, на его лице Намеки ласки и очарованья. Сличи его черты, как письмена, Измерь, какая в каждой глубина,

А если что останется в тумане, Ищи всему в глазах истолкованья. Вот где тебе блаженства полный И переплета лишь недостает.

Как рыба - глуби, с той же силой самой И золотое содержанье книг Нуждается в застежках золотых,

Вот так и ты, подумавши о муже, Не сделаешься меньше или хуже. 
Две первые строки этой речи леди Капулетти обращает к дочери, призывая ее ко вниманию. Далее следует сонет, написанный, как и 126 сонет цикла I609 г. («O thou, my lovely boy, who in thy power...), куплетами пятистопного ямба. Внутренняя организация монолога леди Капулетти следует обычной сонетной схеме:

- в I и 2 катренах (условно назовем их «октетом») она метафорически сравнивает Париса с прекрасной книгой, которая еще только ждет своего переплета, своей обложки. Леди использует два примечательных каламбура: характеризует черты лица Париса как “married” (т. е. «гармонично сочетающиеся друг с другом» и «супружеские»), а также называет Париса “unbound” (в одном значении - «без переплета», в другом - «не связанный ни с кем крепкими узами»);

- в 3 катрене (составляет начало «сестета») леди расписывает завидную участь обложки, которая сможет украсить такую книгу. Мать Джульетты полагает: нет унижения в том, чтобы служить чему-нибудь хорошему обложкой, обрамлением, вместилищем - само́ великое море не стыдится скрывать в своих глубинах чудесную маленькую рыбку;

- наконец, в финальном куплете-«замке» звучит призыв к Джульетте уподобиться богатому переплету - и согласиться на брак с Парисом.

Любопытно, что в этой речи имеются два окольцовывающих двустишия - первое и последнее, - которые, словно верхняя и нижняя покрышки переплета («обложка» = Джульетта), замыкают в себе три внутренние катрена («книгу» = портрет Париса). Окольцовывающие двустишия - пространство, где чувствуется присутствие Джульетты, так как именно там леди Капулетти напрямую обращается к дочери, пытаясь заручиться ее вниманием.

Если убрать эти окольцовывающие двустишия с обращением к невесте (= «покрышки переплета»), то средняя часть речи леди Капулетти (три катрена, состоящие из двустиший) совпадет по форме с сонетом I264 шекспи-

4 Сонет номер г26 издания I6о9 г. завершает часть цикла, обращенную к «юному другу». Как и подобает итоговому сонету, он подхватывает темы, оглашенные в начале этой части. Одна из них - адресованное юноше пожелание уберечь от тлена красоту его лица и фигуры. Сохранить прекрасные черты можно повторив их в детях, передав по наследству физическую привлекательность. Чтобы такая «передача» свершилась, молодой человек должен жениться и обрести потомство. Поэтому матримониальный призыв настойчиво звучит в первых I7 сонетах цикла г6о9 г. Специфика формы г26-го сонета отмечалась неоднократно. Отсутствие у него завершающего двустишия, по устоявшемуся мнению шекспироведов, означает внезапно прерванную жизнь героя. Кроме того, благодаря удале- 
ровского цикла І6о9 г. Имеется между названными стихами и тематическое сходство. В І26 сонете нарисован портрет молодого красавца, который так и не нашел своей «обложки», навсегда оставшись в состоянии “unbound”:

O thou, my lovely boy, who in thy power

Dost hold Time's fickle glass, his sickle, hour;

Who hast by waning grown, and therein

showest

Thy lovers withering, as thy sweet self

growest.

If Nature, sovereign mistress over wrack, As thou goest onwards still will pluck thee

back,

She keeps thee to this purpose, that her skill May time disgrace and wretched minutes kill.

Yet fear her, O thou minion of her pleasure! She may detain, but not still keep,

her treasure:

Her audit (though delayed) answered must be, And her quietus is to render thee.
О, милый мальчик! Времени косы Не убоясь, ты взял его часы. И вот, цветя и набираясь сил, Поклонников своих ты подкосил.
А если мать-Природа не дает Лететь тебе безудержно вперед, Она тебя оберегает тем Чтоб время не смело тебя совсем.

Но берегись! Капризна, неверна, Не станет вечно клад хранить она, И - будет день тот близок иль далек Наступит, наконец, расплаты срок. (Пер. А.М. Финкеля)

В отличие от Париса, желающего сочетаться браком с Джульеттой, юноша сонетов г609 г. избегает семейных уз. И потому посвященные ему три катрена г26 сонета можно рассматривать как антитетичные по отношению к трем четверостишиям сонета Париса. В самом деле:

- в I катрене сонета Париса провозглашается торжество симметрии и гармонии (ср. “every married lineament”), а в I26 сонете царит асимметрия и неестественность (ср. "by waning grown”, "withering/growest”);

нию итогового куплета-замка, сонет приобретает симметричность относительно среднего катрена (как у песочных часов: сосуд / узкая горловина / сосуд) (подробнее о замечаниях литературоведов по этому поводу см.: [3, с. 844-845]). Здесь, сопоставив сонет г26 с декламацией леди Капулетти, мы находим еще одно объяснение его необычной форме: три четверостишия, содержащие портрет молодого красавца, являют собой своего рода замкнутую форму: они создают иллюзию самодостаточности и изолированности. Добавление куплета «разомкнуло» бы этот круг, нарушило бы атмосферу полной «холостяцкой» (ср. “unbound”) отстраненности от всяческих связей. 
- во 2 катрене сонета Париса оглашается, чего именно недостает юноше для достижения полного совершенства (ср. "this unbound lover, / То beautify him, only lacks a cover”). В противовес тому, в г26 сонете утверждается, что совершенство на пути, избранном юношей, недостижимо (“As thou goest onwards still will pluck thee back");

- в 3 катрене сонета Париса прославляется успешный и крепкий союз равных половин: внутреннего и внешнего «сокровищ» (“That book in many's eyes doth share the glory, / That in gold clasps locks in the golden story"). В контраст тому, І26 сонет рисует союз некрепкий и неравный: юноша представлен как игрушка госпожи по имени Время - как сокровище, которое она, набаловавшись, бросит (“She may detain, but not still keep her treasure”).

Таким образом, два сонета Шекспира - І26 сонет цикла І6о9 г. и сонет от лица Париса, произнесенный леди Капулетти, - выглядят как комплементарные (companion sonnets): они дают «асимметричные» ответы на одни и те же вопросы о гармонии и совершенстве, о жизненных и семейных ценностях. К тому же эти шекспировские сонеты схожи своей редкой формой: написаны они куплетами.

Подведем нашим наблюдениям некоторые итоги. В шекспировской пьесе имеются два претендента на руку Джульетты Капулетти: это граф Парис, родственник герцога Веронского, и Ромео Монтекки. Первый - друг семьи Капулетти, достойный, красивый, воспитанный молодой человек, соблюдающий все правила ухаживания. Он был бы Джульетте хорошим, спокойным мужем и добрым другом. Второй жених, казалось бы, совсем неподходящий, «неправильный»: он - наследник вражеского клана, который - пусть и по вдохновению свыше - нарушил в своем сватовстве границы традиционных условностей. Но Джульетта выбрала именно Ромео. Их любви и посвящена вся пьеса.

Эти два типа любовных отношений нашли отражение в двух сонетах, включенных Шекспиром в текст трагедии. Оба сонета «интимные»: в тексте они не выставлены напоказ, а погружены в гущу диалога. Оба сонета строятся на основе развернутых метафор (ср. сонеты-прологи, в которых кончетто отсутствуют). Оба I4-стишия перекликаются с шекспировским сонетным циклом I609 г.: декламация от лица Париса - со г26 сонетом 
(завершающим часть к «юному другу»); диспут Ромео и Джульетты о поцелуе - со г28 сонетом (начало части, адресованной «смуглой даме»). Однако по запасу энергии, заключенной в сонете, по перформативности поэтическое подношение Ромео и подношение Париса несопоставимы. Сонет Ромео оживает в жестах героев и отдается эхом в разных частях пьесы, определяя ее исход: образы, рожденные этим сонетом, повторяются и в финале. Творческий потенциал у сонета Париса гораздо ниже: однажды полюбовавшись этой поэтической вставкой, мы забываем о ней, словно о красочной книжной странице, которую давно перелистнули. 


\section{Список литературы}

I Алексеев М.П. Пушкин и Шекспир // Алексеев М.П. Пушкин: Сравнительно-исторические исследования / АН СССР; Ин-т рус. лит. (Пушкинский Дом). Л.: Наука, Ленингр. отд., 1972. С. 240-280.

2 Красовская В.M. Западноевропейский балетный театр. Очерки истории. От истоков до середины XVIII века. 2-е изд., испр. (г-е изд. г979 г.). СПб.: Планета музыки, 2008. 320 c.

3 Макаров В.С. Примечания // Шекспир У. Сонеты / отв. ред. А.Н. Горбунов. М.: Наука, 20I6. С. 770-868. (Серия «Литературные памятники» РАН).

4 Михайлова-Смольнякова Е.С. Старинные бальные танцы. Эпоха Возрождения. СПб.: Планета музыки, 20Iо. I76 с.

5 Морозов M.M. Сонеты Шекспира в переводах С. Маршака. М.: Сов. писатель, 1948. 256 c.

6 Пушкин А.С. Примечание А.С. Пушкина к «Сцене из трагедии Шекспира: Ромео и Юлия» в переводе П.А. Плетнева // Альманах «Северные цветы на г8зо г.» СПб., І829. XI, 83.

7 Халтрин-Халтурина Е.В. Сонетные вставки в пьесах Шекспира // Шекспир У. Сонеты / отв. ред. А.Н. Горбунов. М.: Наука, 20I6. С. 725-769. (Серия «Литературные памятники» $\mathrm{PAH})$.

Халтрин-Халтурина Е.В. Шекспировские сонеты-диалоги: от «Бесплодных усилий любви» к «Ромео и Джульетте» // Известия РАН. Серия литературы и языка. 2016. Т. 75 , № 4. С. 35-4I.

9 Brissenden A. Shakespeare and the Dance. Atlantic Highlands (USA): Humanities Press Inc., I98I. Reprinted: Alton (UK): Dance Books Ltd, 200I. XII + I45 p.

Io Gill R. Romeo and Juliet: Commentary // Shakespeare W. Romeo and Juliet. Oxford: Oxford Univ. Press, I982. («Oxford School Shakespeare» Series.) Levenson J.L. The Definition of Love: Shakespeare's Phrasing in Romeo and Juliet // Shakespeare Studies. Vol. I5 (1982). P. 21-36. Levenson J.L. Romeo and Juliet before Shakespeare // Studies in Philology. Vol. 8I. № 3 (Summer 1984). P. 325-347.

I3 Perrine L. When Form and Content Kiss / Intention Made the Bliss: The Sonnet in Romeo and Juliet // The English Journal. Vol. 55. № 7 (Oct. 1966). P. 872-874.

I4 Schalkwyk D. Speech and Performance in Shakespeare's Sonnets and Plays. Cambridge: Cambridge Univ. Press, 2002. 262 p. Shakespeare W. Romeo and Juliet / Ed. René Weis. Electronic edition. L.: Bloomsbury Publishing Plc., 20I3. ePub ISBN: 978I408I5I983. ("The Arden Shakespeare” Ser.). Shakespeare W. Sonnets / Ed. with analytic commentary by Stephen Booth. New Haven: Yale Univ. Press, I977. XX +583 p. 
I7 Weis R. Introduction // Shakespeare W. Romeo and Juliet / Ed. René Weis. Electronic edition. L.: Bloomsbury Publishing Plc., 20I3. ePub ISBN: 978I408I5I983. ("The Arden Shakespeare" Ser.).

\section{References}

I Alekseyev M.P. Pushkin i Shekspir [Pushkin and Shakespeare]. Pushkin: Sravnitel'noistoricheskie issledovaniya [Pushkin: A Comparative/Historical Research]. Leningrad, Nauka Publ., 1972, pp. 240-280. (In Russ.)

Krasovskaya V.M. Zapadnoyevropeisky baletny teatr. Ocherki istorii. Ot istokov do serediny I8veka [Ballet Performances in Western Europe. Essays in History. From the Beginnings to the Mid I $8^{\text {th }}$ cent.], 2nd, corr. ed. St. Petersburg, Planeta muzyki Publ., 2008. 320 p. (In Russ.)

3 Makarov V.S. Primechaniya [Notes]. Shekspir. Sonety [Shakespeare's Sonnets], ed. A.N. Gorbunov. Moscow, Nauka Publ., 20I6, pp. 770-868. (In Russ.)

4 Mikhailova-Smol'nyakova E.S. Starinnye bal'nye tantsy. Aepokha Vozrozhdeniya [The Ancient Ballroom Dances. The Age of Renaissance]. St. Petersburg, Planeta muzyki Publ., 20IO. I76 p. (In Russ.)

5 Morozov M.M. Sonety Shekspira v perevodakh Marshaka [Shakespeare's Sonnets in Marshak’s Translation]. Moscow, Sovetsky pisatel’ Publ., I948. 256 p. (In Russ.)

6 Pushkin A.S. Primechaniye Pushkins k "Stsene iz tragedii Shekspira Romeo i Juliya" v perevode P.A. Pletneva [Pushkin's Note to a "Scene from Shakespeare's Romeo and Juliet” in P.A. Pletnyov Translation]. Severnye Tsvety na I830 g. [The Northen Flowers for the year I830]. St. Petersburg, I829. (In Russ.)

$7 \quad$ Haltrin-Khalturina E.V. Sonetnye vstavki v p'esakh Shekspira. [On Inset Sonnets in Shakespeare's Plays]. Shekspir. Sonety [Shakespeare's Sonnets], ed. A.N. Gorbunov. Moscow, Nauka Publ., 20I6, pp. 725-769. (In Russ.)

8 Haltrin-Khalturina E.V. Shekspirovskiye sonety-dialogi: ot "Besplodnykh usilii liubvi” k "Romeo i Dzhul'ette" [Shared Sonnets in Shakespeare: From Love's Labour's Lost to Romeo and Juliet]. Izvestiia Rossiiskoi Akademii Nauk. Seriia Literatury I Iazyka, 2016, vol. 75, no 4, pp. 35-4I. (In Russ.)

9 Brissenden A. Shakespeare and the Dance. Atlantic Highlands (USA), Humanities Press Inc., I98I. Reprinted: Alton (UK), Dance Books Ltd, 200I. XII + I45 p. (In English)

IO Gill R. Romeo and Juliet: Commentary. W. Shakespeare. Romeo and Juliet. Oxford, Oxford Univ. Press, 1982. (“Oxford School Shakespeare” Series.) (In English)

II Levenson J.L. The Definition of Love: Shakespeare's Phrasing in Romeo and Juliet. Shakespeare Studies, vol. I5 (I982), pp. 2I-36. (In English)

I2 Levenson J.L. Romeo and Juliet before Shakespeare. Studies in Philology, vol. 8I, no 3 (Summer I984), pp. 325-347. (In English)

I3 Perrine L. When Form and Content Kiss, Intention Made the Bliss: The Sonnet in Romeo and Juliet. The English Journal, vol. 55, no 7 (Oct. 1966), pp. 872-874. (In English) 
I4 Schalkwyk D. Speech and Performance in Shakespeare's Sonnets and Plays. Cambridge, Cambridge Univ. Press, 2002. 262 p. (In English)

I5 Shakespeare W. Romeo and Juliet, ed. René Weis. Electronic edition. London, Bloomsbury Publishing Plc., 20I3. ePub ISBN: 978I408I5I983. (“The Arden Shakespeare” Ser.). (In English)

I6 Shakespeare W. Sonnets, ed. with analytic commentary by Stephen Booth. New Haven, Yale Univ. Press, I977. XX + 583 p. (In English)

I7 Weis R. Introduction. Shakespeare W. Romeo and Juliet, ed. René Weis. Electronic edition. London, Bloomsbury Publishing Plc., 2013. ePub ISBN: 978I408I51983. ("The Arden Shakespeare" Ser.). 